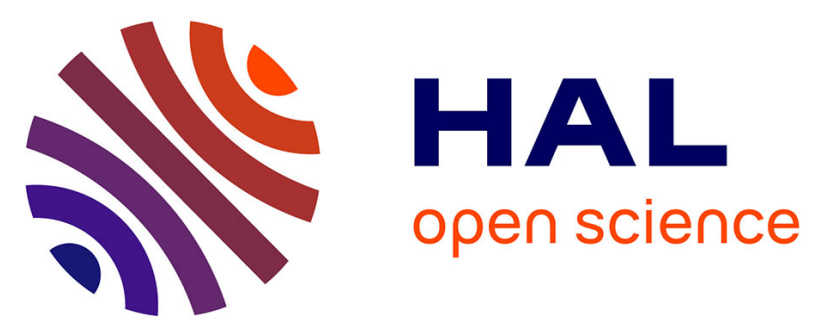

\title{
Highly active composite TiO2-polypyrrole nanostructures for water and air depollution under visible light irradiation
}

Xiaojiao Yuan, Marek Kobylanski, Zhenpeng Cui, Jian Li, Patricia Beaunier, Diana Dragoe, Christophe Colbeau-Justin, Adriana Zaleska-Medynska, Hynd Remita

\section{To cite this version:}

Xiaojiao Yuan, Marek Kobylanski, Zhenpeng Cui, Jian Li, Patricia Beaunier, et al.. Highly active composite $\mathrm{TiO} 2$-polypyrrole nanostructures for water and air depollution under visible light irradiation. Journal of Environmental Chemical Engineering, 2020, 8 (5), pp.104178. 10.1016/j.jece.2020.104178 . hal-03437337

\section{HAL Id: hal-03437337 https://hal.science/hal-03437337}

Submitted on 23 Nov 2021

HAL is a multi-disciplinary open access archive for the deposit and dissemination of scientific research documents, whether they are published or not. The documents may come from teaching and research institutions in France or abroad, or from public or private research centers.
L'archive ouverte pluridisciplinaire HAL, est destinée au dépôt et à la diffusion de documents scientifiques de niveau recherche, publiés ou non, émanant des établissements d'enseignement et de recherche français ou étrangers, des laboratoires publics ou privés. 


\title{
Highly Active Composite $\mathrm{TiO}_{2}$-Polypyrrole Nanostructures for Water and Air Depollution
}

\section{Under Visible Light Irradiation}

Xiaojiao Yuan ${ }^{1}$, Marek P. Kobylanski ${ }^{2}$, Zhenpeng Cui ${ }^{1}$, Jian $\mathrm{Li}^{1}$, Patricia Beaunier ${ }^{3}$, Diana Dragoe ${ }^{4}$, Christophe Colbeau-Justin ${ }^{1}$, Adriana Zaleska-Medynska², Hynd Remita ${ }^{1,5^{*}}$

${ }^{1}$ Institut de Chimie Physique, UMR 8000 CNRS, Université Paris-Saclay, 91405 Orsay, France

${ }^{2}$ Department of Environmental Technology, Faculty of Chemistry, University of Gdansk, 80-308 Gdansk, Poland

${ }^{3}$ Sorbonne Université, CNRS, UMR 7197, Laboratoire de Réactivité de Surface, 75005 Paris, France

${ }^{4}$ Institut de Chimie Moléculaire et des Matériaux d'Orsay, Université Paris-Saclay, 91405 Orsay, France

${ }^{5}$ CNRS, Institut de Chimie Physique, UMR 8000, 91405 Orsay, France

E-mail : hynd.remita@universite-paris-saclay.fr

\begin{abstract}
Engineering photocatalytic materials for solar energy harvesting and environmental remediation is a very promising prospect to solve energy and environment issues. Here we report the preparation of a

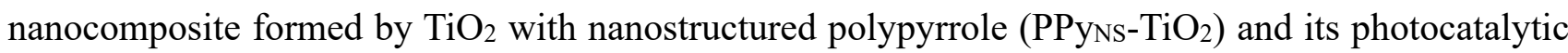
properties. We show that this nanocomposite is very active for water and air treatment under UV and visible light irradiation. This activity is higher than that of bare $\mathrm{TiO}_{2}$ and $\mathrm{PPy}_{\mathrm{N}}$, and much improved compared to that of $\mathrm{TiO}_{2}$-bulk polypyrrole $\left(\mathrm{PPy}_{\text {bulk }}-\mathrm{TiO}_{2}\right)$. The nanostructuration of the conjugated
\end{abstract}


polymer is a key factor for the photocatalytic activity of the composite. The large enhancement of the photocatalytic activity is ascribed to the heterojunction between $\mathrm{PPyNs}_{\text {and }} \mathrm{TiO}_{2}$, which broadens the absorption of visible light and facilitates the charge carriers' separation. These results foresee the composite $\mathrm{PPyns}_{-}-\mathrm{TiO}_{2}$ photocatalyst for water and air purification in environment remediation.

Keywords: Polypyrrole nanostructures, Organic-inorganic hybrid nanocomposites, Conjugated polymers, Titanium dioxide, Photocatalysis, Depollution. 


\section{Introduction}

Semiconductor photocatalysts based on $\mathrm{TiO}_{2}$ have attracted increasing attention for water and air treatment owing to the low cost of titania, its high photochemical properties, excellent stability and outstanding photocatalytic activity [1-6]. Nevertheless, the large band gap of $\mathrm{TiO}_{2}(3.2 \mathrm{eV}$ for anatase and $3.0 \mathrm{eV}$ for rutile) induces a photocatalytic activity only under ultraviolet light $(5 \%$ of the solar light), which limits its commercial applications in photocatalysis. Besides, high charge carrier recombination in $\mathrm{TiO}_{2}$ also results in a poor photocatalytic activity. In order to improve its photocatalytic activity, numerous approaches have been developed such as noble metal loading [7-13], non-metal doping [14-16], heterojunction construction [4, 13, 17-19] or modification with conjugated polymers (CPs) [20-27]. Organic-inorganic hybrid materials have attracted much attention in solar energy conversion and photocatalytic degradation of organic pollutants [28, 29]. Among them, modification of $\mathrm{TiO}_{2}$ with conjugated polymer nanostructures (CPNs) presents promising photocatalysis application under visible light. CPs with their unique extending $\pi$ - $\pi$ * electron system which can serve as stable photosensitizers inpouring the electrons into the conduction band (CB) of semiconductors [26, 30-33]. For example, composite materials composed of $\mathrm{TiO}_{2}$ nanoparticles bound to large PPy polymer particles surface were reported to be photoactive under visible-light irradiation [27]. Although there are already some investigations on photocatalytic performance of $\mathrm{TiO}_{2}-\mathrm{PPy}$, some fundamental questions are still not answered. In previous studies, little attention was paid to the life time of photo-induced charge carriers and charge transfer route between $\mathrm{TiO}_{2}$ and $\mathrm{PPy}$ nanostructures under ultraviolet and visible light, separately and the photocatalytic properties of $\mathrm{TiO}_{2}-\mathrm{PPy}$ nanocomposite for air treatment has not been reported [20, 22, 23, 27, 34]. 
CPs present high mobility of charge carriers, narrow and tunable band gap, good stability and high absorption coefficients towards the visible region or near-infrared light. These excellent and special properties indicate that CPs are promising photosensitizers or photocatalysts under the solar light illumination. We demonstrated in our previous works that nanostructured CPs such as poly(diphenylbutadyine) PDPB, Poly(3,4-ethylenedioxythiophene) PDOT, Poly(3-hexylthiophene) (P3HT) and polypyrrole (PPy), exhibit higher photocatalytic property in visible region contrary to their bulk counterpart, and this activity is much higher than that of plasmonic $\mathrm{TiO}_{2}[31,33,35]$. These CPNs are synthesized in soft templates formed by hexagonal or lamellar mesophases and polymerized by UV light or radiolysis [30, 36, 37].

In this work, we modified commercial P25 $\mathrm{TiO}_{2}$ with nanostructured PPy (PPyNs) (prepared in soft templates formed by hexagonal mesophases) for photodegradation of organic pollutants (methyl orange and phenol as model water pollutants and toluene as air pollutant). The nanocomposite shows an important increase of the photocatalytic performance under ultraviolet and visible light compared to bare $\mathrm{TiO}_{2}$ and PPyns, and most interestingly to $\mathrm{PPy}_{\text {bulk}}-\mathrm{TiO}_{2}$. The improved photocatalytic performance of $\mathrm{PPy}_{\mathrm{NS}}-\mathrm{TiO}_{2}$ is due to highest surface area and less defects in the nanostructure PPy and to the wide light absorption and increased charge separation efficiency owing to the heterojunction formation. The $\mathrm{PPyns}_{-}-\mathrm{TiO}_{2}$ composite photocatalyst shows high stability and recyclability. The kinetics of charge carriers is also discussed. This work offers a facile and cheap way to fabricate the heterojunction in organic-inorganic hybrid materials interface, and the composite nanomaterial represents a promising photocatalyst for water treatment and indoor application such as air treatment. 


\section{Experimental}

\subsection{Chemicals and materials}

Pyrrole (Py) (98\%), iron chloride $\left(\mathrm{FeCl}_{3}, \geq 97 \%\right)$, sodium dodecyl sulfate (SDS, 98.5\%), cyclohexane (99.7\%), n-pentanol (>99\%), methyl orange (MO), phenol, sodium chloride $(\mathrm{NaCl}$, $\geq 99.5 \%$ ), ethanol ( $\geq 99 \%$ ), were bought from Aldrich Chemical Co., and toluene was purchased P.P.H. "STANLAB" (Lublin, Poland). All the reagents were used without further purification. Commercial P25 titanium dioxide purchased from EVONIK has been used as support material, which consists of crystalline phases rutile (14-17\%), anatase (73-85\%) and amorphous titania (0-13\%) [38]. Distilled water was used throughout the experiment.

\subsection{Photocatalyst preparation}

PPy nanostructures (PPyns) were obtained by surfactant-mediated soft templating (lamellar mesophases) method: We used the synthetic protocol reported in our previous work with some modifications [31]. In short, first, the monomer pyrrole $(100 \mu \mathrm{L})$ and $1.6 \mathrm{mg}$ of the SDS surfactant were dissolved in $4 \mathrm{~mL}$ aqueous $\mathrm{NaCl}(0.1 \mathrm{M})$. Then $6 \mathrm{~mL}$ cyclohexane and $1 \mathrm{~mL}$ pentanol were then added to the solution, the obtained mesophase doped by monomer was labeled as A. The mesophase B was prepared: An aqueous solution $(4 \mathrm{~mL})$ containing $0.1 \mathrm{M} \mathrm{FeCl}_{3}$ and SDS surfactant (1.6 mg) was added under stirring to cyclohexane $(6 \mathrm{~mL})$ and pentanol $(1 \mathrm{~mL})$. The achieved mixture $(\mathrm{A}+\mathrm{B})$ was vigorously stirred with vortex, and kept $12 \mathrm{~h}$ for complete polymerization. The polymerization takes place in the confined aqueous domain. The PPy nanostructures powder was extracted with a mixture ethanol and distilled water.

The composite $\mathrm{PPy}_{\mathrm{N}}-\mathrm{TiO}_{2}$ was obtained by sonication $(5 \mathrm{~min})$ in ethanol followed by $2 \mathrm{~h}$ stirring 
(Fig. S1a). PPybulk was synthesized without any soft template (polymerization in water using $\mathrm{FeCl}_{3}$ as oxidant) [31]. PPybulk- $\mathrm{TiO}_{2}$ was prepared with the sample procedure used for $\mathrm{PPyNS}_{\mathrm{N}}-\mathrm{TiO}_{2}$ preparation.

Modification of $\mathrm{TiO}_{2}$ with $\mathrm{Ag} \mathrm{NPs}\left(\mathrm{Ag}-\mathrm{TiO}_{2}\right)$ was obtained by radiolytic reduction (using a panoramic gamma source) of $\mathrm{Ag}^{+}$on $\mathrm{TiO}_{2}$ in suspension in water (containing $0.1 \mathrm{M}$ of 2-propanol as $\mathrm{HO}^{\bullet}$ scavenger) as reported in our previous work $[10,12]$. Here, $\mathrm{Ag}-\mathrm{TiO}_{2}$ plasmonic photocatalyst is taken as a model photocatalyst to be compared with $\mathrm{PPyNS}_{\mathrm{NiO}}$ due to its good photocatalytic activity under visible light.

\subsection{Characterization}

UV-visible spectra of PPyns-TiO 2 , PPyns and $\mathrm{TiO}_{2}$ were recorded with a Cary 5000 Series, Agilent Technologies spectrophotometer using an integrating sphere and with $\mathrm{KBr}$ as a reference sample. The morphology of the synthesized materials was observed by transmission electron microscopy (TEM, JEOL JEM 2010 UHR operating at $200 \mathrm{kV}$ ).

The crystalline structure of the samples was studied using an X-ray diffraction (XRD) (PHILIPSPW 3040/60) system with $\mathrm{Cu} \mathrm{K} \alpha$ radiation from 10 90.

FT-IR (Fourier transform infrared) spectra were recorded using a FT-IR spectrometer (Bruker Vertex 70) with a diamond/ZnSe accessory (PIKEMIRACLE crystal plate) and a dectector LN-MCT Mid equipped with a cooling system (liquid nitrogen).

X-ray photospectroscopy (XPS) surveys were conducted on a $\mathrm{K} \alpha \mathrm{X}$-ray Photoelectron Spectrometer equipped with a hemispherical electron energy analyzer ( $\mathrm{Mg} \mathrm{K} \alpha$ radiation and monochromatic Al Ka, PHI 5000 VersaProbe II microprobe) under ultrahigh vacuum. For charge 
correction, $\mathrm{C} 1$ spectra at $284.5 \mathrm{eV}$ as standard was considered. The samples were dispersed in ethanol and then supported on Si plate for measurements.

Time-resolved microwave conductivity (TRMC) technique was used to investigate the photogenerated charge carriers' dynamics of the as-prepared samples under UV and visible light excitation. A pulsed and tunable laser source $(200 \sim 2000 \mathrm{~nm})$ equipped with an optical parametric oscillator (OPO; EKSPLA, NT342B) was used to excite the samples and a Gunn diode (30 GHz) was used to generate microwaves. TRMC technique measures the relative change $\left(\frac{\Delta P(t)}{p}\right)$ in microwave power reflected from a semiconductor material during its excitation by a laser pulse. This change $(\Delta \sigma(t))$ could be related to small perturbation of the samples conductivity, as shown in the following formula:

$$
\frac{\Delta P(t)}{p}=A \Delta \sigma(t)=A e \mu_{e} \Delta n_{e}(t) \quad \text { (equation 1) }
$$

In $\mathrm{TiO}_{2}$ based compounds, the electron mobility $\left(\mu_{e}\right)$ is much higher than of $\mathrm{h}^{+}$. Therefore, $\Delta \sigma(t)$ is mainly due to excess electrons. $\Delta n_{e}(t)$ is the excess free electron number at time t. A (sensitivity factor) is time independent and relies on the conductivity of the semiconductor and the microwave frequency.

The primary data given by TRMC signals are its maximum value $\left(I_{\max }\right)$, which corresponds the quantity of the excess electrons generated by the laser pulse, and its decay, which is owing to the decrease of excess electrons.

The photoelectrochemical performance of the as-prepared samples were measured by Origalys workstation with a three-electrode system (the prepared sample electrode, Pt foil electrode and $\mathrm{Ag} / \mathrm{AgCl}$ electrode were acted as working, counter and reference electrode, respectively). The 
photoinduced current density with time $(i-t)$ curves were observed at a potential of $-200 \mathrm{~V}(v s$. $\mathrm{Ag} / \mathrm{AgCl}$ ). The electrochemical impedance spectroscope (EIS) measurements were conducted in 0.1 $\mathrm{M} \mathrm{Na}_{2} \mathrm{SO}_{4}$ solution. The working electrodes were prepared by a highly homogeneous sample film on FTO substrate. In briefly, $3 \mathrm{mg}$ of sample was dispersed in $3 \mathrm{~mL}$ ethanol by stirring. Then, the solution was spread on the FTO (fluorine doped tin oxide) substrate. Finally, the working electrodes were achieved after they were dried at room temperature. EIS was recorded with AC voltage amplitude of $10 \mathrm{mV}$, and a frequency range from $0.1 \mathrm{~Hz}$ to $1000 \mathrm{~Hz}$ at $0.2 \mathrm{~V}(v \mathrm{~s} . \mathrm{Ag} / \mathrm{AgCl})$.

\subsection{Photoactivity tests}

The photocatalytic property of $\mathrm{PPyNs}^{-\mathrm{TiO}_{2}}$ was investigated for degradation of methyl orange (MO, 500 ppm) and phenol $\left(\mathrm{C}_{6} \mathrm{H}_{5} \mathrm{OH}, 50 \mathrm{ppm}\right)$ in water and toluene $\left(\mathrm{C}_{7} \mathrm{H}_{8}, 200 \mathrm{ppm}\right)$ in air.

Phenol is one of the most commonly used test molecule. It was proposed by Serpone et al. as a standard test molecule, it shows some advantages [39]:

- It does not degrade by photolysis or catalysis.

- It has an absorption band at $269 \mathrm{~nm}$ and can be detected by UV-visible spectroscopy.

- Its mechanism of degradation is known (the main intermediates being benzoquinone, hydroquinone and catechol) [40].

- It can be completely mineralized into $\mathrm{CO}_{2}$ and $\mathrm{H}_{2} \mathrm{O}$.

- Its adsorption on the surface of $\mathrm{TiO}_{2}$ is very weak.

- It is a real pollutant of water.

Methyl orange is a toxic azo-dye used in textile industry. 
Before irradiation, $3 \mathrm{mg}$ of the photocatalyst ( $\mathrm{PPyns}_{2}-\mathrm{TiO}_{2}$, bare $\mathrm{PPyns}_{2} \mathrm{TiO}_{2}$ or $\mathrm{PPybulk}_{-} \mathrm{TiO}_{2}$ ) was dispersed in $3 \mathrm{~mL}$ of water containing phenol (initial concentration $\mathrm{C}_{0}=50 \mathrm{ppm}$ ) or $\mathrm{MO}$ (initial concentration $\mathrm{C}_{0}=500 \mathrm{ppm}$ ) used as model organic pollutant. In order to ensure adsorption-desorption equilibrium, the mixture was stirred for $2 \mathrm{~h}$ in the dark. Control tests for photolysis (without photocataysts) were conducted under UV light (Fig. S2). Then, the samples were exposed to a UVvisible light (Oriel $300 \mathrm{~W}$ Xenon lamp) or a visible light (Oriel $300 \mathrm{~W}$ Xenon lamp with a 420-nm cut off filter) under $\mathrm{O}_{2}$ bubbling. $400 \mu \mathrm{L}$ of the mixture were taken out every 5 min under UV irradiation and $1 \mathrm{~h}$ under visible light, respectively. Then, the suspension was centrifuged to separate the catalyst from the solution. High pressure liquid chromatography (HPLC, Agilent Technologies 1260 Infinity) was used to measure the concentration of phenol. The calibration of phenol was shown in Fig. S3. And the concentration of $\mathrm{MO}$ was determined by UV-vis spectrophotometric method. The photocatalytic activity of the sample was estimated by the expression $\left(\mathrm{C}_{0}-\mathrm{C}\right) / \mathrm{C}_{0} \times 100 \%\left(\mathrm{C}_{0}\right.$ : initial concentration; $\mathrm{C}$ : present concentration after every interval of time).

To estimate the quantity of the mineralized pollutant, we used Total organic carbon (TOC) (Shimadzu TOC-LCSH).

Toluene was used as an air pollutant model. The photocatalytic tests in gas phase were conducted in a gas reactor with the volume of $30 \mathrm{~cm}^{3}$. The reactor for photodegradation of gas is equipped with the LED diodes, which emit monochromatic irradiation $(375 \mathrm{~nm}, 415 \mathrm{~nm}$ or $465 \mathrm{~nm})$. The light intensity of the irradiation corresponded to $10 \mathrm{~mW} / \mathrm{cm}^{2}$. A slide of glass $(2 \mathrm{~cm} \times 2 \mathrm{~cm})$ was covered by $\mathrm{PPyns}, \mathrm{TiO}_{2}$, and $\mathrm{PPyns}_{-}-\mathrm{TiO}_{2}$ film, respectively, and then the samples were placed on the bottom of the reactor and sealed with a quartz window (Fig. S1d). The initial toluene concentration was 200 
ppm. For UV and visible irradiation, we used LED arrays with $\lambda=375 \mathrm{~nm}, 415 \mathrm{~nm}$ and $465 \mathrm{~nm}$. Before illumination, the reactor was kept in the dark for $10 \mathrm{~min}$. To analyze the concentration of toluene by gas chromatography we used a GC, Clarus 500, PerkinElmer.

\section{Results and discussions}

\subsection{Characterizations of $\mathrm{PPy}_{\mathrm{NS}}-\mathrm{TiO}_{2}$ composite}

The optical absorption properties of bare $\mathrm{TiO}_{2}$ and PPyns, and $\mathrm{PPyns}-\mathrm{TiO}_{2}$ composite were investigated by UV-Vis DRS. In Fig. 1a, $\mathrm{TiO}_{2}$ presents an absorption edge at $400 \mathrm{~nm}$ owing to the appearance of rutile, while the absorption edge of $\mathrm{PPyNs}_{\mathrm{N}}-\mathrm{TiO}_{2}$ is located at $490 \mathrm{~nm}$. The composite PPyns-TiO 2 shows higher absorption in the visible range because of the interaction between PPyns and $\mathrm{TiO}_{2}$ in heterojunction leading to a red shift of the absorbance towards the visible region. Fig. S4 shows a broad absorption of PPyns from $200 \mathrm{~nm}$ to $800 \mathrm{~nm}$. The optical band gap (Eg) of photocatalysts samples can be evaluated by DRS spectra (Kubelka-Munk method). The Eg of $\mathrm{PPyns}_{\mathrm{N}} \mathrm{TiO}_{2}$ and $\mathrm{TiO}_{2}$ are $1.95 \mathrm{eV}$ and $2.93 \mathrm{eV}$, respectively, which could be calculated by the plots of $(\alpha \mathrm{h} v)^{1 / 2} v s$ hv $(\alpha-$ absorption coefficient; $\mathrm{h}$ - Planck constant; $v$ - light frequency) (Fig. 1b)[41]. The band gap of PPyns is about $2.01 \mathrm{eV}$, which was calculated in our previous work [31]. Fig. 1 and Fig. S5 show broader light absorption and narrower band gap of $\mathrm{PPyNs}^{-\mathrm{TiO}_{2}}$ and $\mathrm{PPy}_{\text {bulk}}-\mathrm{TiO}_{2}$ compared with unmodified $\mathrm{TiO}_{2}$. The broad absorption in visible light and narrow band gap $(\mathrm{Eg}<3.2 \mathrm{eV})$ of catalyst are beneficial for photocatalytic activity under visible light. 
(a)

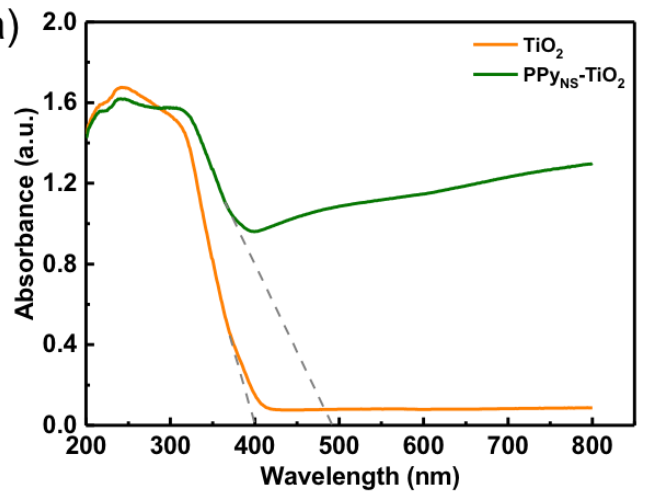

(c)

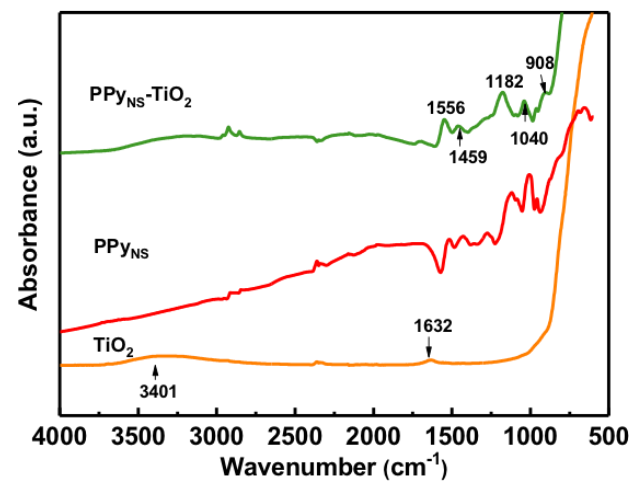

(b)

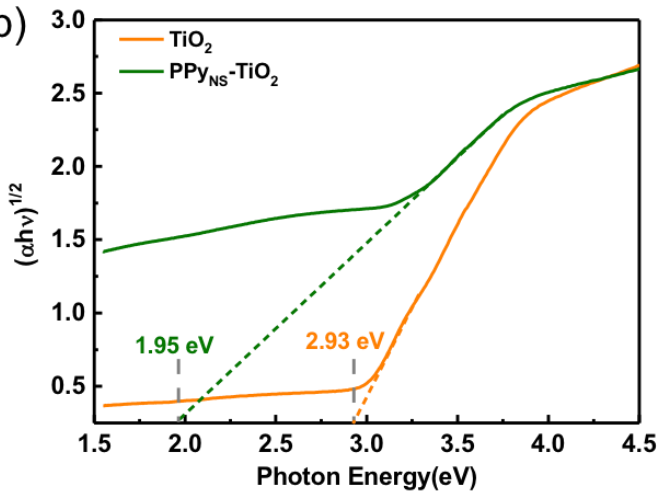

(d)

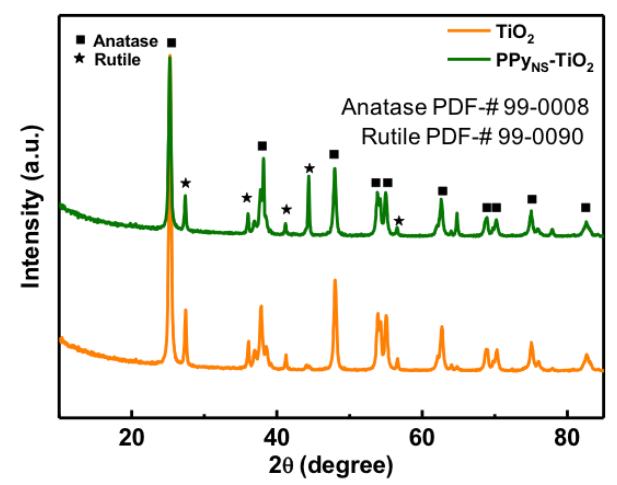

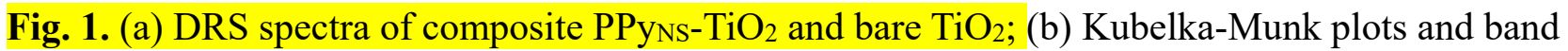
energy estimation of $\mathrm{PPyns}_{\mathrm{N}}-\mathrm{TiO}_{2}$ and $\mathrm{TiO}_{2}$; (c) FTIR spectra of $\mathrm{TiO}_{2}, \mathrm{PPyNS}_{\mathrm{N}}$ and $\mathrm{PPyNS}_{\mathrm{N}}-\mathrm{TiO}_{2}$; (d) Xray diffraction pattern for $\mathrm{TiO}_{2}$ and $\mathrm{PPyns}_{-} \mathrm{TiO}_{2}$.

FTIR is used to analyze the chemical structures of the as-prepared samples. The typical characteristic spectrum of $\mathrm{PPyNs}_{-}-\mathrm{TiO}_{2}$ composite within the wavenumber range of $500 \mathrm{~cm}^{-1} \sim 4000$ $\mathrm{cm}^{-1}$ is shown in Fig. 1c. The bands at $1556 \mathrm{~cm}^{-1}$ and $1459 \mathrm{~cm}^{-1}$ are assigned to the $\mathrm{C}=\mathrm{C}$ and $\mathrm{C}-\mathrm{C}$ stretching vibration of pyrrole ring, respectively. The peaks at $1182 \mathrm{~cm}^{-1}$ and $1040 \mathrm{~cm}^{-1}$ relate to the $\mathrm{N}-\mathrm{C}$ stretching band and $=\mathrm{C}-\mathrm{H}$ in-plane deformation vibration $[42,43]$. The peak at $908 \mathrm{~cm}^{-1}$ is due to $\mathrm{C}-\mathrm{H}$ out-of-plane bending vibrations [22]. The wide absorption peak at $500 \mathrm{~cm}^{-1}$ to $800 \mathrm{~cm}^{-1}$ refers to the flexural vibration of $\mathrm{Ti}-\mathrm{O}-\mathrm{Ti}$ in $\mathrm{TiO}_{2}$, and the weak peak at $1632 \mathrm{~cm}^{-1}$ is vibration of $\mathrm{O}-\mathrm{H}$ in water adsorbed on $\mathrm{TiO}_{2}$ surface [44]. The broad peak at $3401 \mathrm{~cm}^{-1}$ is ascribed to the $\mathrm{O}-\mathrm{H}$ vibration of 
water molecular. The characteristic peaks of $\mathrm{PPyNS}_{-} \mathrm{TiO}_{2}$ composite are shifted compared to neat PPyns and $\mathrm{TiO}_{2}$ indicating the interaction between $\mathrm{PPy}_{\mathrm{N}}$ and $\mathrm{TiO}_{2}$.

Fig. 1d presents the XRD patterns of photocatalysts. For pristine $\mathrm{TiO}_{2}$, the $\mathrm{XRD}$ patterns presents

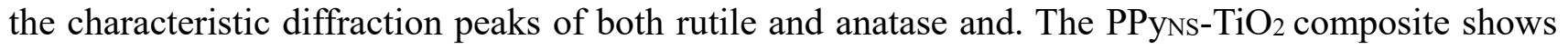
similar diffraction patterns with $\mathrm{TiO}_{2}$, and no other peaks were observed, which reveals the high purity of the sample.

TEM and SEM images of $\mathrm{TiO}_{2}$ and PPy nanostructures and $\mathrm{PPyNs}_{-} \mathrm{TiO}_{2}$ composite are shown in Fig. 2 and Fig. S1b-c, respectively. $\mathrm{TiO}_{2}-\mathrm{P} 25$ particles show irregular shapes with diameters of 5-10 nm (Fig. 2a and Fig. S6), and the lattice spacing $d=0.25 \mathrm{~nm}$ of $\mathrm{TiO}_{2}$ correspond to the (101) planes of rutile phase. PPyns are homogeneous in size (about $40 \mathrm{~nm}$ diameter) (Fig.2b and Fig. S1b) [31]. PPyns- $-\mathrm{TiO}_{2}$ composite exhibits higher contrast than amorphous organic PPy nanostructures $\left(\mathrm{TiO}_{2}\right.$ nanoparticles appear more dark) (Fig. 2c-d and Fig. S1c).
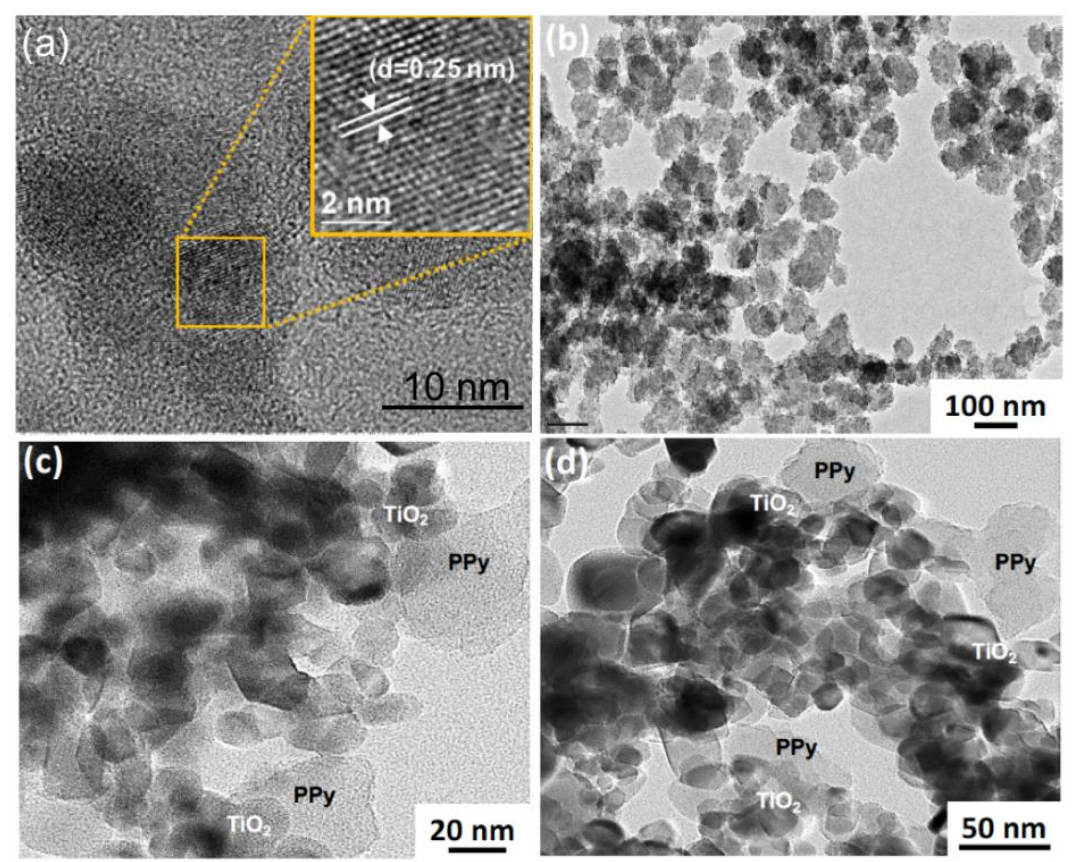

Fig. 2. HRTEM images of $\mathrm{TiO}_{2}$ with the inter-planar distance corresponding to the (101) planes of rutile phase in inset (a); TEM images of PPyNs (b) and $\mathrm{PPyNs}_{\mathrm{NiO}}$ (c-d). 
XPS was utilized to characterize the surface chemical components of $\mathrm{PPyNS}_{\mathrm{N}} \mathrm{TiO}_{2}$ composite (Fig. S7 and Fig.3). The XPS survey spectra presents the elements of Ti, O, C, N (Fig.S7). Fig. 3a illustrates the XPS spectra of the Ti $2 p$ region. Ti $2 p$ spectrum shows a binding energy at $459.4 \mathrm{eV}$ and $465.1 \mathrm{eV}$ for $\mathrm{Ti} 2 \mathrm{p}_{3 / 2}$ and $\mathrm{Ti} 2 \mathrm{p}_{1 / 2}$, respectively, corresponding to the Ti $2 p$ spectrum from $\mathrm{TiO}_{2}$. The signals of displayed peaks from C-C (288.3 eV), $\beta-\mathrm{C}(284.1 \mathrm{eV}), \alpha-\mathrm{C}(285.0 \mathrm{eV})$ and other small peaks from C$\mathrm{N}(286.0 \mathrm{eV}), \mathrm{C}-\mathrm{O}(287.3 \mathrm{eV})$ and carbonates $(289.4 \mathrm{eV})$ are corresponding to C $1 \mathrm{~s}$ of PPyns (Fig. 3b). The signal at $400.0 \mathrm{eV}$ was assigned to the $-\mathrm{NH}$ - group of the pyrrole unit, and the $-\mathrm{N}^{+}$- (polaron) and $=\mathrm{N}$ - defects of PPy structures are at $401.6 \mathrm{eV}$ and $398.1 \mathrm{eV}$, respectively (Fig. 3c). The signals at 530.6 $\mathrm{eV}$ and $532.9 \mathrm{eV}$ correspond to the $\mathrm{O} 1 \mathrm{~s}$ of $\mathrm{TiO}_{2}$ and $\mathrm{SiO}_{2}$ (Si plate as a support) (Fig. 3d)[34]. All these results demonstrate that there is no new component produced in the composite $\mathrm{PPyns}_{\mathrm{TiO}}$, which is consistent with the XRD results (Fig. 1d).
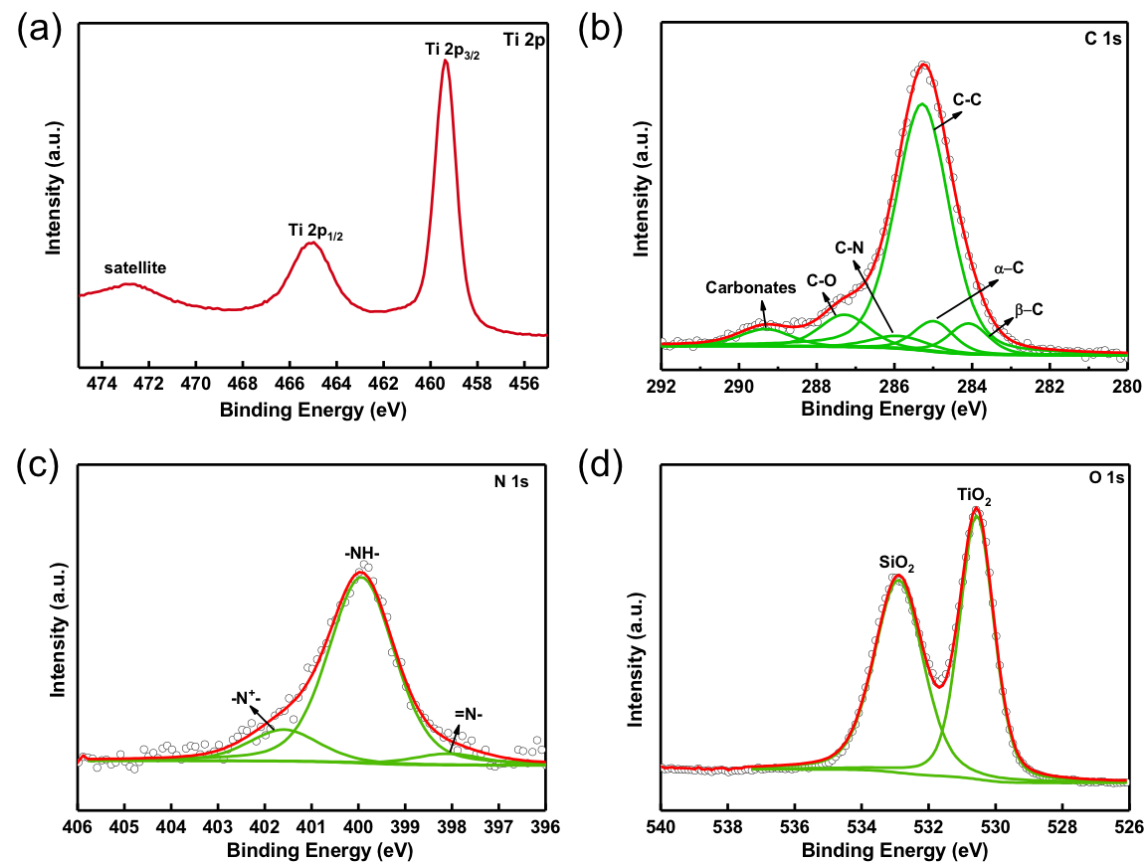

Fig.3. XPS spectra of PPyns-TiO 2 (a) Ti 2p of $\mathrm{TiO}_{2}$, (b) C 1s of PPyns, (c) N 1s of PPyns and (d) O 1s of $\mathrm{TiO}_{2}$ and $\mathrm{SiO}_{2}$ 
TRMC technique was conducted to study the dynamics of charge carriers in the $\mathrm{TiO}_{2}$-based composites [45]. The maximum data $\left(I_{\max }\right)$ provided by TRMC signals indicate the excess electrons number generated by the laser pulse and the decay of the signal is attributed to recombination and trapping processes representing the life-time of charge carriers. The samples were excited at different wavelengths under UV and visible light ( $360 \mathrm{~nm}, 420 \mathrm{~nm}, 450 \mathrm{~nm}, 500 \mathrm{~nm})$.

As stated before, in $\mathrm{TiO}_{2}$, electrons are much more mobile than holes, and the TRMC signals are largely corresponding to the $\mathrm{e}^{-}$in the conduction band (CB). At $360 \mathrm{~nm}$ excitation (Fig. 4a), above $\mathrm{TiO}_{2}$ bandgap, both bare $\mathrm{TiO}_{2}$ and $\mathrm{PPyns}_{-}-\mathrm{TiO}_{2}$ present high $\mathrm{Imax}_{\operatorname{mal}}$ values. The signal of bare $\mathrm{TiO}_{2}$ is higher than signal of the $\mathrm{PPy}_{\mathrm{NS}}-\mathrm{TiO}_{2}$ composite, which indicates more charge carriers generated in pure $\mathrm{TiO}_{2}$ under UV light. The decay is quite identical for both compounds. The lower signal decay in PPyns-TiO 2 may be due to PPyns shield effect, fast recombination effect, or fast electron trapping [46]. The similar decays show that no real important influence on charge carrier lifetime is detected.

However, under visible excitation, below $\mathrm{TiO}_{2}$ bandgap, at $420 \mathrm{~nm}$ (Fig. 4b), $450 \mathrm{~nm}$ (Fig. 4c) and $500 \mathrm{~nm}$ (Fig. 4d), the signals of $\mathrm{PPyNs}^{-} \mathrm{TiO}_{2}$ increased relatively with the higher excitation wavelength, and the $\mathrm{I}_{\max }$ signal of $\mathrm{PPyNS}_{\mathrm{NiO}} \mathrm{TiO}_{2}$ is higher than that of $\mathrm{TiO}_{2}$ at $450 \mathrm{~nm}$ and $500 \mathrm{~nm}$ excitation. The signal decay is also slower in the composite material, and this is related to longer life time of charge carriers due to less $\mathrm{e}^{-}-\mathrm{h}^{+}$recombination or rapid electron trapping. The signal intensity of $\mathrm{PPyns}_{\mathrm{N}} \mathrm{TiO}_{2}$ at $500 \mathrm{~nm}$ is slightly lower than that obtained with $450 \mathrm{~nm}$ excitation. These results demonstrate the formation of a heterojunction between PPyss and $\mathrm{TiO}_{2}$, which induces electrons transfer from $\mathrm{PPyNs}_{\mathrm{N}}$ to $\mathrm{TiO}_{2}$ under visible light and extension of the life time of charge carriers under UV and visible light. 

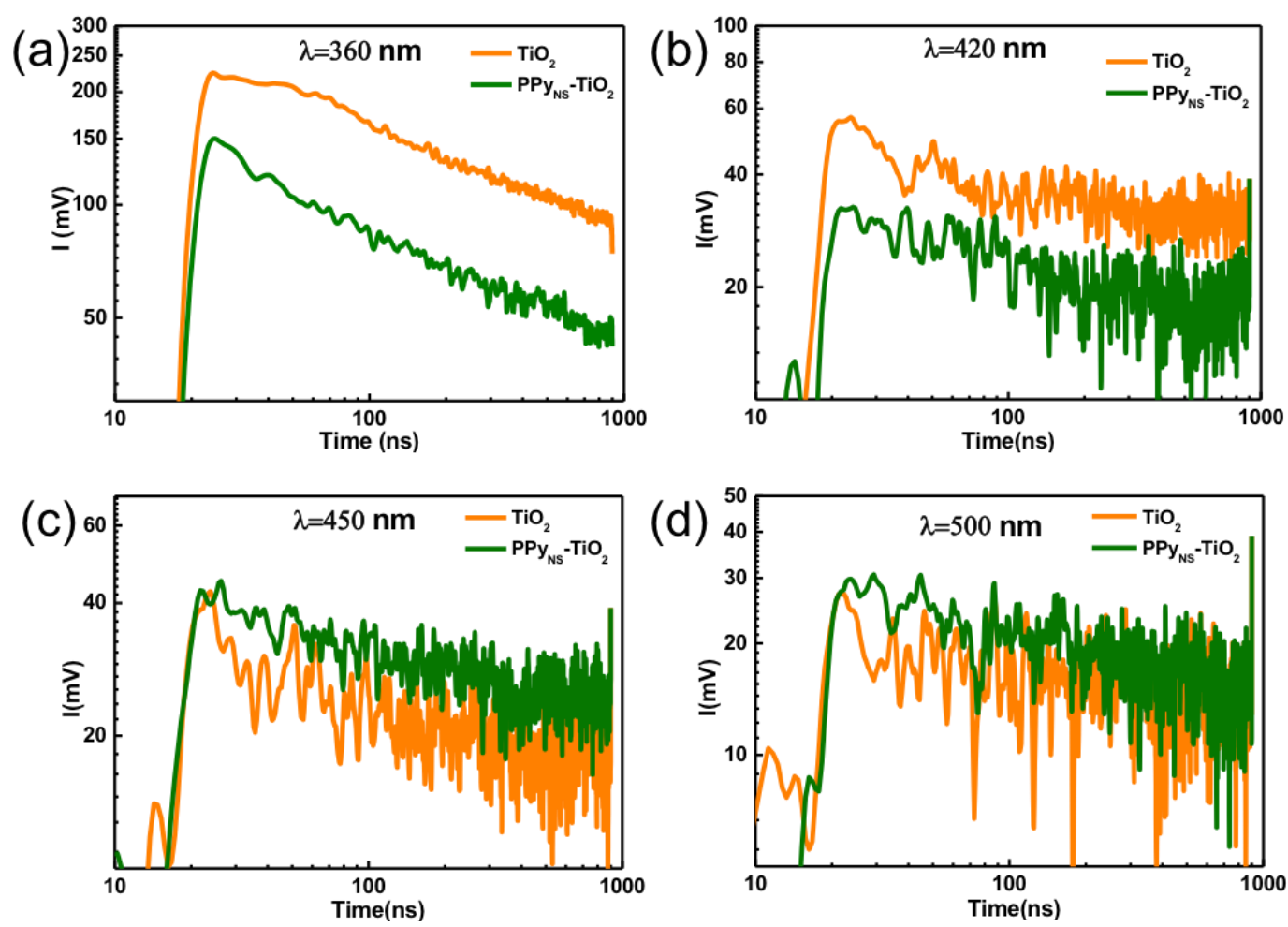

Fig. 4. TRMC signals of $\mathrm{PPyNS}_{\mathrm{N}}-\mathrm{TiO}_{2}$ and $\mathrm{TiO}_{2}$ at different excitation wavelengths: (a) $360 \mathrm{~nm} \mathrm{UV}$ irradiation, (b) $420 \mathrm{~nm}$, (c) $450 \mathrm{~nm}$, and (d) $500 \mathrm{~nm}$ visible irradiation. The corresponding laser energy was $0.9,2.3,2.3$ and $2.3 \mathrm{~mJ} \cdot \mathrm{cm}^{-2}$, respectively.

Fig. 5a shows the photoinduced i-t curve of $\mathrm{PPyns}^{-\mathrm{TiO}_{2}}$ and $\mathrm{TiO}_{2}$ photoanodes under $\mathrm{UV}$-vis light irradiation. The photocurrent of $\mathrm{PPyNS}_{-} \mathrm{TiO}_{2}$ photoanode was about $80 \mu \mathrm{A} \cdot \mathrm{cm}^{-2}$, which is twice higher than that of $\mathrm{TiO}_{2}$ photoanode, implying $\mathrm{TiO}_{2}$ modification with PPyns increases generation, separation and transfer of charge carriers leading to the enhanced photoelectrochemical property [47]. EIS Nyquist plots showed that $\mathrm{PPyns}_{-} \mathrm{TiO}_{2}$ exhibits a smaller semicircle compared to the $\mathrm{TiO}_{2}$ (Fig. 5b), suggesting that PPyns may provide electron transfer channel for the PPyns-TiO2/FTO photoanode, which increases the life time of electrons and ultimately enhances the photocatalytic activity [48, 49]. 

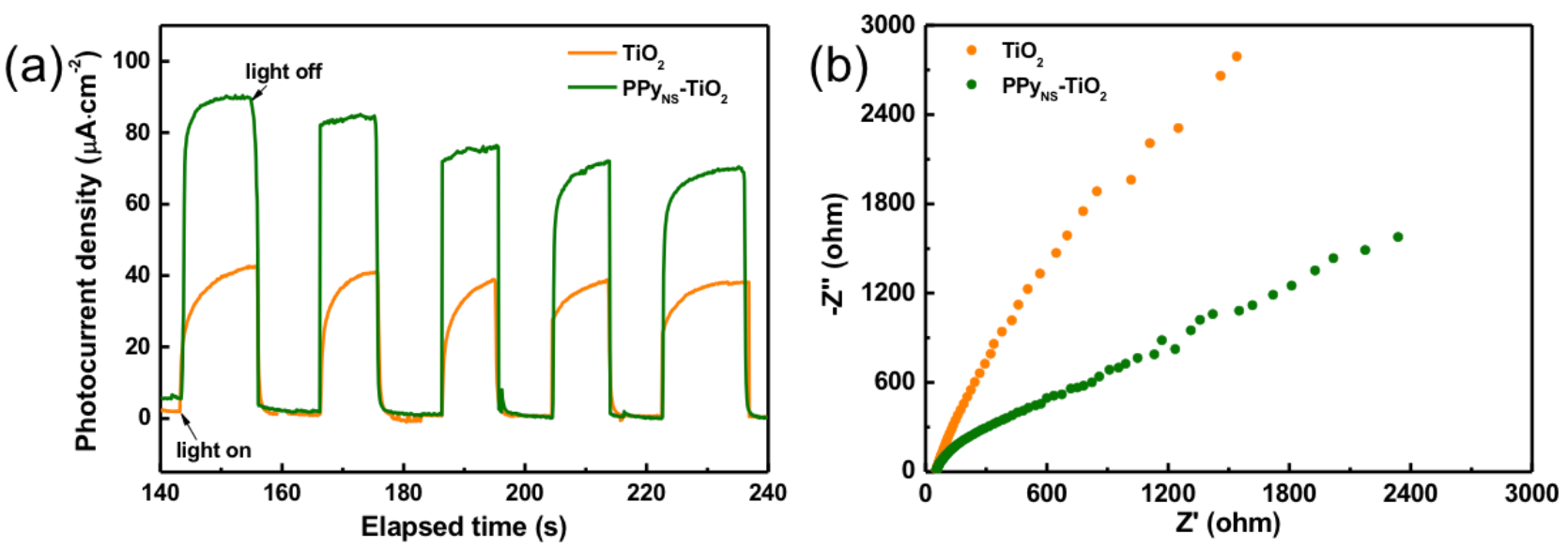

Fig. 5. (a) Photocurrent transient responses at a constant potential of $-200 \mathrm{mV}$ for $\mathrm{TiO}_{2}$ and $\mathrm{PPyNs}^{-}$

$\mathrm{TiO}_{2}$ FTO electrodes under UV-vis light irradiation; (b) the EIS curve of $\mathrm{PPyns}_{\mathrm{N}}-\mathrm{TiO}_{2}$ and $\mathrm{TiO}_{2}$ photoanodes under dark at the potential of $0.2 \mathrm{~V}$ vs $\mathrm{Ag} / \mathrm{AgCl}$ in $0.1 \mathrm{M} \mathrm{Na}_{2} \mathrm{SO}_{4}$ neutral electrolyte.

\subsection{Photocatalytic tests}

The photocatalytic activity of the $\mathrm{PPyNs}_{\mathrm{N}} \mathrm{TiO}_{2}$ composite was studied for degradation of model pollutants in water and in air.

MO and phenol were used as a water model pollutant. The effect of the mass ratios between PPyns and $\mathrm{TiO}_{2}$ (PPyns: $\left.\mathrm{TiO}_{2}=0: 1,1: 2,1: 1,2: 1,1: 0\right)$ for photocatalytic degradation of $\mathrm{MO}$ was investigated and the best mass ratio with the highest photocatalytic activity is $1: 1$ (see in Fig. S8). Fig. 6 and Fig. S9 shows the degradation of methyl orange and phenol in aqueous solution. Under UV-vis light, the effective degradation of MO up to $100 \%$ takes place in 20 min in the presence of $\mathrm{PPyNS}_{\mathrm{NiO}} \mathrm{TiO}_{2}$ and PPybulk- $\mathrm{TiO}_{2}$ composite, while this total degradation is achieved after $45 \mathrm{~min}$ irradiation with bare $\mathrm{TiO}_{2}$ and with PPyns only 78\% degradation is obtained after $5 \mathrm{~h}$ (Fig. S10). The photocatalytic activity of PPy- $\mathrm{TiO}_{2}$ is close to that of plasmonic $\mathrm{TiO}_{2}\left(\mathrm{TiO}_{2}\right.$ surface modified with $\mathrm{Ag}$ nanoparticles $)$ as shown in Fig. 6a [12]. Bare $\mathrm{TiO}_{2}$ is known to be not active under visible light irradiation. $\mathrm{PPyns}_{\mathrm{N}}-\mathrm{TiO}_{2}$ 
composite shows a good photocatalytic activity: $70 \%$ of degradation rate of $\mathrm{MO}$ is achieved after $4 \mathrm{~h}$ under visible light. This activity is much higher than that of bare PPyNs (18\% degradation after $4 \mathrm{~h})$ and also much higher than that of plasmonic $\mathrm{TiO}_{2}(20 \%$ degradation after $5 \mathrm{~h})$, and interestingly higher than that of $\mathrm{PPy}_{\text {bulk }}-\mathrm{TiO}_{2}(41 \%$ degradation after 4 h) (see in Fig. 6b)

These photocatalysts were also tested for phenol degradation. Fig. 6c shows that phenol is completely degraded in $20 \mathrm{~min}$ in the presence of $\mathrm{PPyNS}_{\mathrm{T}} \mathrm{TiO}_{2}, \mathrm{PPy}$ bulk- $\mathrm{TiO}_{2}$, or $0.5 \% \mathrm{Ag}-\mathrm{TiO}_{2}$ under UV-vis light. Besides, $100 \%$ degradation rate is achieved, respectively with bare $\mathrm{TiO}_{2}$ after 25 min and with bare PPyns after $4.5 \mathrm{~h}$. The activity of $\mathrm{PPybulk}_{-} \mathrm{TiO}_{2}$ and plasmonic $\mathrm{TiO}_{2}$ are very similar for phenol degradation under visible light. The photocatalytic activity of $\mathrm{PPyNs}_{\mathrm{N}} \mathrm{TiO}_{2}$ is much higher than that of PPybulk- $\mathrm{TiO}_{2}, 0.5 \% \mathrm{Ag}-\mathrm{TiO}_{2}$ and bare PPyNS (no photocatalytic activity of bare $\mathrm{TiO}_{2}$ ). The degradation rates of phenol are respectively: 55\%, 25\%, 15\% and 10\% with $\mathrm{PPyns}_{\mathrm{N}} \mathrm{TiO}_{2}, \mathrm{PPybulk}_{-} \mathrm{TiO}, 0.5 \% \mathrm{Ag}-$ $\mathrm{TiO}_{2}$ and bare PPyns after $4 \mathrm{~h}$ irradiation under visible light (Fig. 6d, and Fig. S11 and Fig. S12). TOC (total organic carbon) measurements indicate the decontamination level of water. $91 \%$ of phenol were mineralized after 20 min of UV irradiation in the presence of $\mathrm{PPyns}_{\mathrm{N}}-\mathrm{TiO}_{2}$. Table $\mathrm{S} 1$ shows some photocatalytic results for water treatment reported for other composite materials based on $\mathrm{TiO}_{2}$ and conjugated polymers for comparison with the present work: Our photocatalyst $\left(\mathrm{PPyNs}_{\mathrm{N}} \mathrm{TiO}_{2}\right)$ shows a higher photocatalytic activity under visible light. Note that the comparison is a rough assessment due to the different experimental conditions such as light source, catalysts quality, pollutant type etc. 
(a)
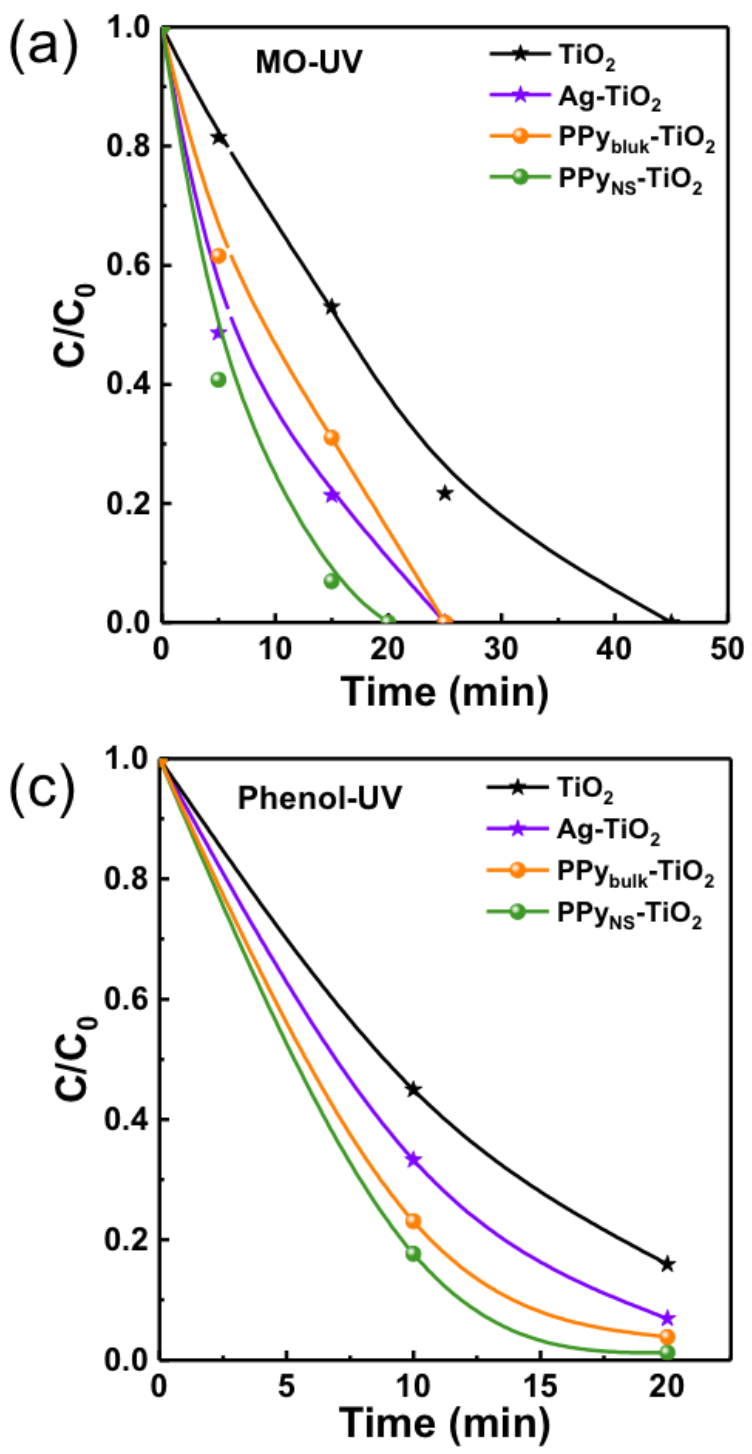

(b)

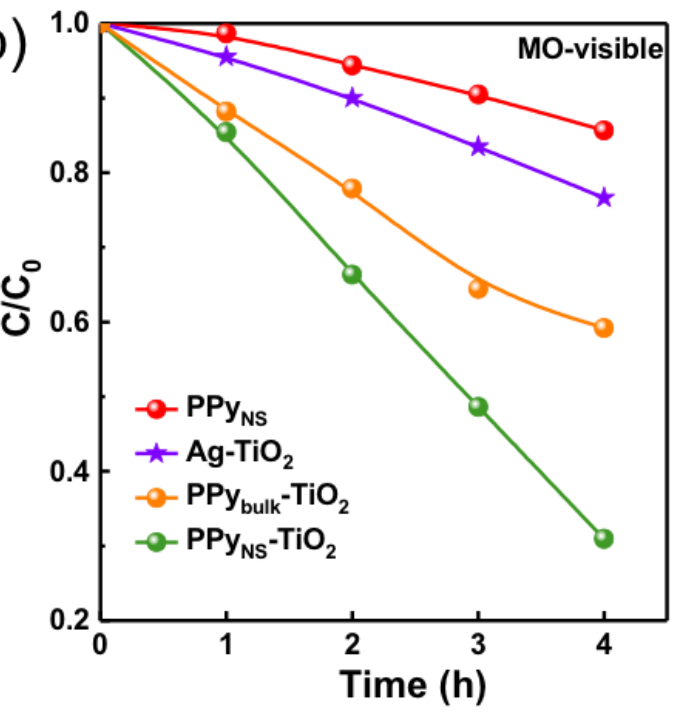

(d)

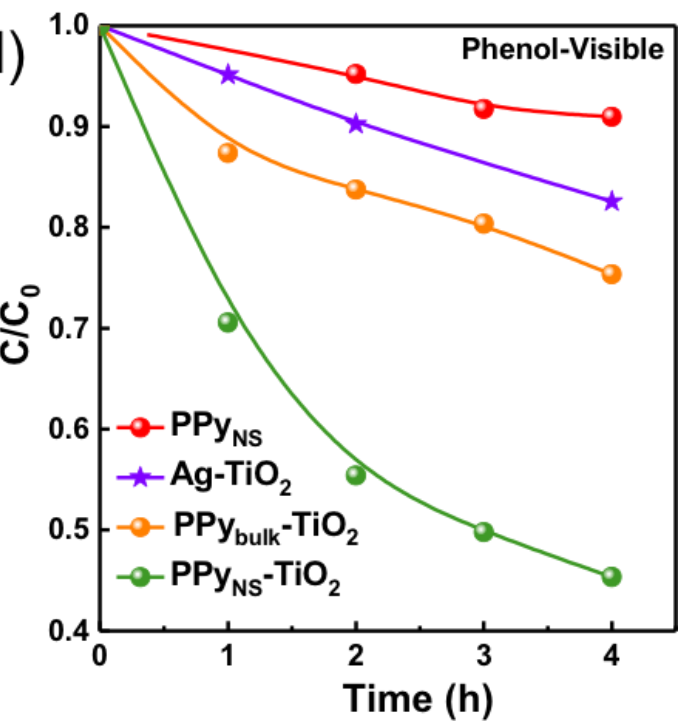

Fig. 6. Photocatalytic degradation rate of $\mathrm{MO}\left(\mathrm{C}_{0}=500 \mathrm{ppm}\right)$ in the presence of as-prepared samples under UV (a) and visible light irradiation (b); photocatalytic degradation rate of phenol under UV (c) and visible light irradiation (d).

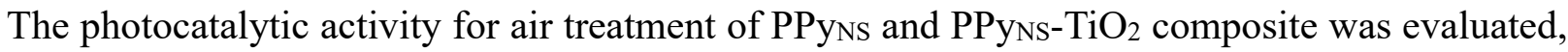
and toluene was taken as model pollutant. Fig 7 shows toluene degradation at different irradiation wavelength (375 nm, $415 \mathrm{~nm}$ and $465 \mathrm{~nm})$. Under UV irradiation $(\lambda=375 \mathrm{~nm}), \mathrm{TiO}_{2}$ shows the best 
photocatalytic activity compared to PPyns and $\mathrm{PPyns}_{\mathrm{T}} \mathrm{TiO}_{2}$ : After 50 min irradiation, the degradation rate with $\mathrm{TiO}_{2}$ is $100 \%$, while with $\mathrm{PPyNs}$ and $\mathrm{PPyns}_{-}-\mathrm{TiO}_{2}$ it is, $49 \%$ and $92 \%$ respectively. The photodegradation rate of $\mathrm{PPyns}_{\mathrm{N}}-\mathrm{TiO}_{2}$ is twice higher than that of pure PPyNs under UV light (Fig. 7a). More importantly, under visible light $(\lambda=415$ and $465 \mathrm{~nm}), \mathrm{PPyns}^{-\mathrm{TiO}_{2}}$ shows better photocatalytic performance than $\mathrm{PPyns}_{\mathrm{N}}\left(\mathrm{TiO}_{2}\right.$ presents no photocatalytic activity under visible light). The degradation rates of $\mathrm{PPyns}_{\mathrm{TiO}}$ are $80 \%(\lambda=415 \mathrm{~nm})$ and $55 \%(\lambda=465 \mathrm{~nm})$ after $100 \mathrm{~min}$, respectively, which are much higher than that obtained with PPyNs $(45 \%$ under $\lambda=415 \mathrm{~nm}$ and $33 \%$ under $\lambda=465 \mathrm{~nm}$ irradiation) (Fig. 7b-c).
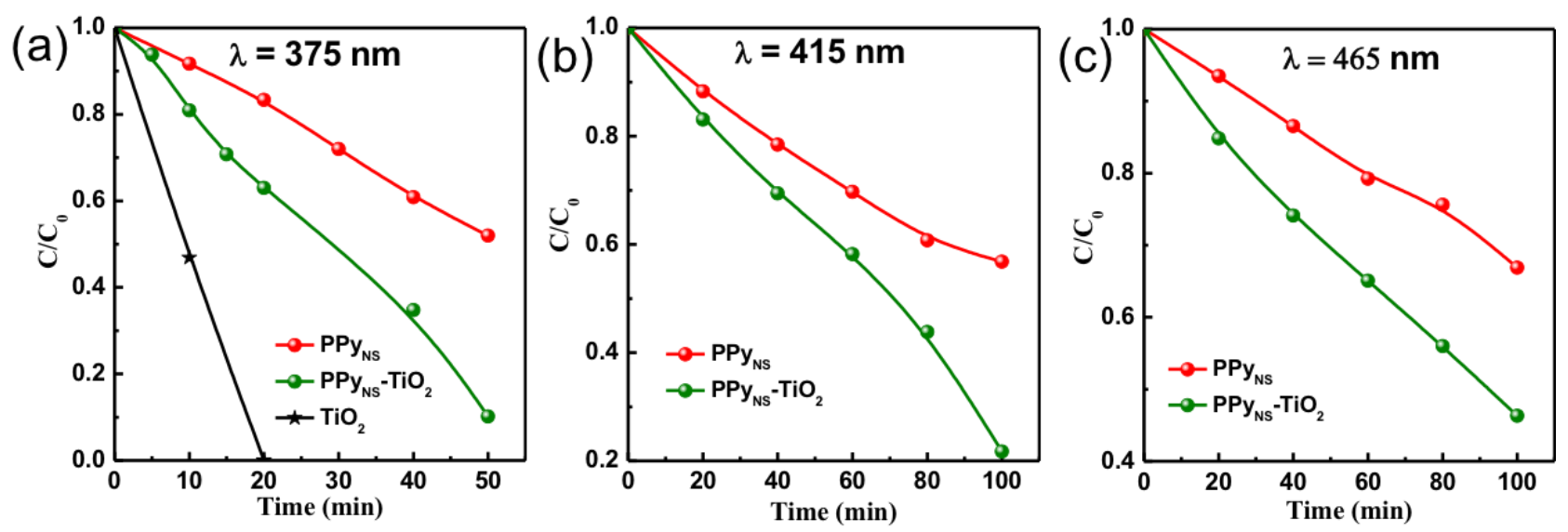

Fig. 7. Photocatalytic activity of PPyns and $\mathrm{PPyns}_{-} \mathrm{TiO}_{2}$ for the toluene degradation under (a) $\lambda=375 \mathrm{~nm}$, (b) $415 \mathrm{~nm}$, and (c) $465 \mathrm{~nm}$ irradiation, respectively.

The results show that $\mathrm{PPyNs}-\mathrm{TiO}_{2}$ composites are very efficient for $\mathrm{MO}$, phenol and toluene degradation under visible light irradiation. The formation of a $p-n$ heterojunction between PPy nanostructures and $\mathrm{TiO}_{2}$ decreased the recombination of photogenerated charge-carriers and enhanced the photocatalytic performance of the composite $\mathrm{PPyns}_{-} \mathrm{TiO}_{2}$. 
In order to satisfy the practical application, the stability and reusability of the photocatalyst was investigated. The photocatalytic activity of $\mathrm{PPyns}_{-}-\mathrm{TiO}_{2}$ is stable after 6 cycles as shown in Fig. S13 Fig. S14. These results indicate that $\mathrm{PPyNs}_{-}-\mathrm{TiO}_{2}$ is a very promising photocatalyst for water and air treatment and other photocatalytic applications.

\subsection{Photocatalytic mechanism}

A huge number of defects could be accumulated at the contact interface of various solids and the energy levels of the interface are quasi-continuous, exhibiting alike properties to conductors. This contact interface can also produce low electric resistance Ohmic contacts and serve as the center of charge carriers' recombination [50].

CPs behave as classical organic semiconductors. The nanostructutration of a conjugated polymer is a pivotal factor for its photocatalytic activity. The morphology and size of the photocatalytic nanomaterials have an important effect on their photocatalytic performance, as demonstrated for $\mathrm{TiO}_{2}$ for example [51, 52] or for CP nanostructures [31-33]. The difference in the photocatalytic property between nano and bulk CPs may be owing to larger sizes, larger surface areas, and more defects in bulk CPs, which are responsible for the $\mathrm{e}^{-}-\mathrm{h}^{+}$recombinations [31, 32].

Under UV irradiation, the photoinduced $\mathrm{e}^{-}$in the $\mathrm{CB}$ of $\mathrm{TiO}_{2}$ can recombine with the $\mathrm{h}^{+}$in the highest occupied orbital (HOMO) of PPyns via the intimate interface resulting the separation of photogenerated charge carriers (see Fig. 8a), which explains the decreased intensity signal of PPyns$\mathrm{TiO}_{2}$ in TRMC measurement at the excitation of $365 \mathrm{~nm}$ and $400 \mathrm{~nm}$ wavelength compared with bare $\mathrm{TiO}_{2}$. In this case, the oxidative reaction and reductive species are produced in the $\mathrm{VB}$ band of $\mathrm{TiO}_{2}$ 
$\left(\mathrm{h}^{+}+\mathrm{OH}^{-} \rightarrow{ }^{\circ} \mathrm{OH},+2.7 \mathrm{~V}\right.$ vs. $\mathrm{NHE}$ at $\left.\mathrm{pH}=0\right)$ and the lowest unoccupied orbital (LUMO) of PPyns $\left(\mathrm{e}^{-}\right.$ $+\mathrm{O}_{2} \rightarrow \mathrm{O}_{2}{ }^{--},-0.046 \mathrm{~V}$ vs. NHE at $\mathrm{pH}=0$ ), respectively [53]. This proposed mechanism is highly in agreement with the results of TRMC and photocatalytic properties under UV irradiation.

However, the higher yield and longer life time of charge carriers from the TRMC measurements and higher photocatalytic activity in the presence of $\mathrm{PPyNs}_{\mathrm{NiO}} \mathrm{TiO}_{2}$ composite compared to pristine $\mathrm{TiO}_{2}$ under visible light excitation, another possible photocatalytic mechanism can be proposed for PPyNS$\mathrm{TiO}_{2}$ (see Fig. 8b). Under visible light irradiation, only PPyns can be photoexcited and act as a photosensitizer. Owing to the internal electric field function, the $\mathrm{e}^{-}$in the LUMO of PPyns could be transferred to that of $\mathrm{CB}$ of $\mathrm{TiO}_{2}$. Photogenerated $\mathrm{h}^{+}$located on the HOMO of PPyNs can participate in the oxidative reaction [54]. As a result, the redox reaction happens in the $\mathrm{CB}$ of $\mathrm{TiO}_{2}$ (reductive reaction: $\mathrm{A} \rightarrow \mathrm{A}^{-}$) and $\mathrm{HOMO}$ of PPyNs (oxidative reaction: $\mathrm{D} \rightarrow \mathrm{D}^{+}$), and the effective charge separation can extend the life time of generated $\mathrm{e}^{-}$and $\mathrm{h}^{+}$and then enhance photocatalytic activity.

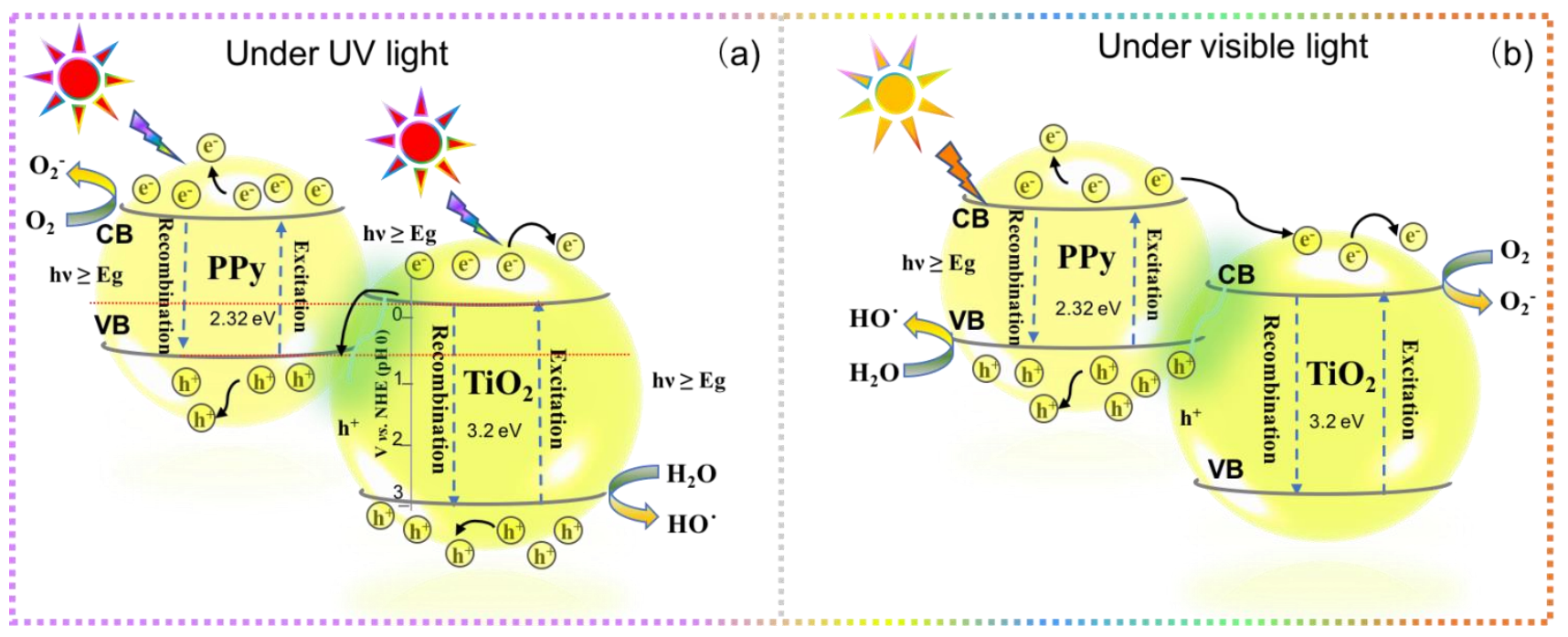

Fig. 8. Proposed photocatalytic mechanism for the $\mathrm{PPyNS}_{\mathrm{N}}-\mathrm{TiO}_{2}$ system and charge transfer mechanisms under UV light (a), and under visible light irradiation (b). 


\section{Conclusions}

We have prepared a highly photoactive $\mathrm{PPyNs}_{\mathrm{N}}-\mathrm{TiO}_{2}$ nanocomposite under visible for environmental pollution remediation. $\mathrm{PPyns}-\mathrm{TiO}_{2}$ presents a red-shift of the absorption band edge and a significant reduction of the band gap $(1.95 \mathrm{eV})$. Our experiments demonstrate that for water and air treatment PPy nanostructures modified with $\mathrm{TiO}_{2}$ exhibit under visible light higher photocatalytic activity than plasmonic $\mathrm{TiO}_{2}, \mathrm{PPy}_{\mathrm{N}}$ and $\mathrm{PPy}$ bulk- $\mathrm{TiO}_{2}$. This enhancement of the photocatalytic activity is due to the nanostructuration of the $\mathrm{CP}$ and the heterojunction formation at the interface between PPyns and $\mathrm{TiO}_{2}$, which promotes the seperation of photoinduced $\mathrm{e}^{-}$and $\mathrm{h}^{+}$.

Interstingly, the composite $\mathrm{PPyNS}_{\mathrm{N}} \mathrm{TiO}_{2}$ has much higher photocatalytic performance than PPybulk$\mathrm{TiO}_{2}$ : Indeed, conjugated polymers nanostructuration is a pivotal factor for photocatalytic applications. Highest surface area and less number of defects in nanostructured polymers (which induce less electron-hole recombinations), lead to higher photocatalytic activity compared to their bulk conterparts [31-33]. The photocatalytic activity is stable with cycling.

This work provides a facile way to develop cheap and very active organic-inorganic hybrid nanocomposite materials for air and water treatment. This stable nanocomposite can also find applications in self cleaning surfaces. Future works will also focus on its modification with cocatalysts based on abondant elements for water splitting.

\section{Acknowledgements}

X.Y. gratefully acknowledges the financial support from China Scholarship Council (CSC). This work was supported by the IDEX Paris-Saclay and IRS MOMENTOM. 


\section{Reference}

[1] K. Nakata, A. Fujishima, $\mathrm{TiO}_{2}$ photocatalysis: Design and applications, Journal of Photochemistry $\begin{array}{llllll}\text { and } & \text { Photobiology } & \text { C: } & \text { Photochemistry } & \text { Reviews, } & 13\end{array}$ (2012) https://doi.org/10.1016/j.jphotochemrev.2012.06.001.

[2] K. Hashimoto, H. Irie, A. Fujishima, $\mathrm{TiO}_{2}$ photocatalysis: a historical overview and future prospects, Japanese Journal of Applied Physics, $44 \quad$ (2005) 8269-8285. https://iopscience.iop.org/article/10.1143/JJAP.44.8269/meta.

[3] L. Yang, E.Y. Liya, M.B. Ray, Degradation of paracetamol in aqueous solutions by $\mathrm{TiO}_{2}$ photocatalysis, Water Research, 42 (2008) 3480-3488. https://doi.org/10.1016/j.watres.2008.04.023.

[4] D. Sánchez-Rodríguez, M.G.M. Medrano, H. Remita, V. Escobar-Barrios, Photocatalytic properties of $\mathrm{BiOCl}_{-} \mathrm{TiO}_{2}$ composites for phenol photodegradation, Journal of Environmental Chemical Engineering, 6 (2018) 1601-1612. https://doi.org/10.1016/j.jece.2018.01.061.

[5] M.G. Méndez-Medrano, E. Kowalska, M. Endo-Kimura, K. Wang, B. Ohtani, D. Bahena Uribe, J.L. Rodríguez-López, H. Remita, Inhibition of Fungal Growth Using Modified $\mathrm{TiO}_{2}$ with Core@ Shell Structure of Ag@ CuO Clusters, ACS Applied Bio Materials, 2(2019) 5626-5633. https://doi.org/10.1021/acsabm.9b00707.

[6] H. Kaur, S. Kumar, N. Verma, P. Singh, Role of $\mathrm{pH}$ on the photocatalytic activity of $\mathrm{TiO}_{2}$ tailored by W/T mole ratio, Journal of Materials Science: Materials in Electronics, 29 (2018) 16120-16135. https://doi.org/10.1007/s10854-018-9701-0.

[7] Y. Choi, M.S. Koo, A.D. Bokare, D.-h. Kim, D.W. Bahnemann, W. Choi, Sequential process combination of photocatalytic oxidation and dark reduction for the removal of organic pollutants and $\mathrm{Cr}$ (VI) using Ag/TiO, Environmental Science \& Technology, 51 (2017) 3973-3981. https://doi.org/10.1021/acs.est.6b06303.

[8] V. Vaiano, G. Iervolino, D. Sannino, J.J. Murcia, M.C. Hidalgo, P. Ciambelli, J.A. Navío, Photocatalytic removal of patent blue $\mathrm{V}$ dye on $\mathrm{Au}-\mathrm{TiO}_{2}$ and $\mathrm{Pt}-\mathrm{TiO}_{2}$ catalysts, Applied Catalysis $\mathrm{B}$ : Environmental, 188 (2016) 134-146. https://doi.org/10.1016/j.apcatb.2016.02.001.

[9] E. Kowalska, H. Remita, C. Colbeau-Justin, J. Hupka, J. Belloni, Modification of titanium dioxide with platinum ions and clusters: application in photocatalysis, The Journal of Physical Chemistry C, 112 (2008) 1124-1131. https://doi.org/10.1021/jp077466p.

[10] E. Grabowska, A. Zaleska, S. Sorgues, M. Kunst, A. Etcheberry, C. Colbeau-Justin, H. Remita, Modification of titanium (IV) dioxide with small silver nanoparticles: application in photocatalysis, The Journal of Physical Chemistry C, 117 (2013) 1955-1962. https://doi.org/10.1021/jp3112183. 
[11] Z. Hai, N. El Kolli, D.B. Uribe, P. Beaunier, M. José-Yacaman, J. Vigneron, A. Etcheberry, S. Sorgues, C. Colbeau-Justin, J. Chen, Modification of $\mathrm{TiO}_{2}$ by bimetallic $\mathrm{Au}-\mathrm{Cu}$ nanoparticles for wastewater treatment, Journal of Materials Chemistry A, 1 (2013) 10829-10835. https://doi.org/10.1039/C3TA11684K.

[12] M. Méndez-Medrano, E. Kowalska, A. Lehoux, A. Herissan, B. Ohtani, D. Bahena, V. Briois, C. Colbeau-Justin, J. Rodríguez-López, H. Remita, Surface modification of $\mathrm{TiO}_{2}$ with Ag nanoparticles and $\mathrm{CuO}$ nanoclusters for application in photocatalysis, The Journal of Physical Chemistry C, 120 (2016) 5143-5154. https://doi.org/10.1021/acs.jpcc.5b10703.

[13] M. Méndez-Medrano, E. Kowalska, A. Lehoux, A. Herissan, B. Ohtani, S. Rau, C. Colbeau-Justin, J. Rodríguez-López, H. Remita, Surface modification of $\mathrm{TiO}_{2}$ with $\mathrm{Au}$ nanoclusters for efficient water treatment and hydrogen generation under visible light, The Journal of Physical Chemistry C, 120 (2016) 25010-25022. https://doi.org/10.1021/acs.jpcc.6b06854.

[14] Y. Zhang, Z. Zhao, J. Chen, L. Cheng, J. Chang, W. Sheng, C. Hu, S. Cao, C-doped hollow TiO 2 spheres: in situ synthesis, controlled shell thickness, and superior visible-light photocatalytic activity, $\begin{array}{llllll}\text { Applied } & \text { Catalysis } & \text { B: } & \text { Environmental, } & 165 & \text { (2015) }\end{array}$ https://doi.org/10.1016/j.apcatb.2014.10.063.

[15] J. Shao, W. Sheng, M. Wang, S. Li, J. Chen, Y. Zhang, S. Cao, In situ synthesis of carbon-doped $\mathrm{TiO}_{2}$ single-crystal nanorods with a remarkably photocatalytic efficiency, Applied Catalysis B: Environmental, 209 (2017) 311-319. https://doi.org/10.1016/j.apcatb.2017.03.008.

[16] T.M. Khedr, S.M. El-Sheikh, A. Hakki, A.A. Ismail, W.A. Badawy, D.W. Bahnemann, Highly active non-metals doped mixed-phase $\mathrm{TiO}_{2}$ for photocatalytic oxidation of ibuprofen under visible light, Journal of Photochemistry and Photobiology A: Chemistry, 346 (2017) 530-540. https://doi.org/10.1016/j.jphotochem.2017.07.004.

[17] Y. Xia, Q. Li, K. Lv, M. Li, Heterojunction construction between $\mathrm{TiO}_{2}$ hollowsphere and $\mathrm{ZnIn}_{2} \mathrm{~S}_{4}$ flower for photocatalysis application, Applied Surface Science, 398 (2017) 81-88. https://doi.org/10.1016/j.apsusc.2016.12.006.

[18] X.-j. Wang, W.-y. Yang, F.-t. Li, J. Zhao, R.-h. Liu, S.-j. Liu, B. Li, Construction of amorphous $\mathrm{TiO}_{2} / \mathrm{BiOBr}$ heterojunctions via facets coupling for enhanced photocatalytic activity, Journal of Hazardous Materials, 292 (2015) 126-136. https://doi.org/10.1016/j.jhazmat.2015.03.030.

[19] P. Zhang, L. Yu, X.W. Lou, Construction of Heterostructured $\mathrm{Fe}_{2} \mathrm{O}_{3}-\mathrm{TiO}_{2}$ Microdumbbells for Photoelectrochemical Water Oxidation, Angewandte Chemie, 130 (2018) 15296-15300. https://doi.org/10.1002/anie.201808104. 
[20] L. Yang, Y. Yu, J. Zhang, F. Chen, X. Meng, Y. Qiu, Y. Dan, L. Jiang, In-situ fabrication of diketopyrrolopyrrole-carbazole-based conjugated polymer/ $\mathrm{TiO}_{2}$ heterojunction for enhanced visible light photocatalysis, Applied Surface Science, $434 \quad$ (2018) 796-805. https://doi.org/10.1016/j.apsusc.2017.10.176.

[21] Y. Wen, S. Liu, Q. Zhang, Y. Zhang, Z. Yang, A. Zhu, Partially conjugated polyvinyl chloridemodified $\mathrm{TiO}_{2}$ nanoparticles for efficient visible-light-driven photocatalytic reduction of aqueous $\mathrm{Cr}$ (VI), Materials Letters, 163 (2016) 262-265. https://doi.org/10.1016/j.matlet.2015.10.109.

[22] F. Gao, X. Hou, A. Wang, G. Chu, W. Wu, J. Chen, H. Zou, Preparation of polypyrrole/TiO 2 nanocomposites with enhanced photocatalytic performance, Particuology, 26 (2016) 73-78. https://doi.org/10.1016/j.partic.2015.07.003.

[23] E.R. Macedo, P.S. Oliveira, H.P. de Oliveira, Synthesis and characterization of branched polypyrrole/titanium dioxide photocatalysts, Journal of Photochemistry and Photobiology A: Chemistry, 307 (2015) 108-114. https://doi.org/10.1016/j.jphotochem.2015.04.013.

[24] J. Zhang, H. Yang, S. Xu, L. Yang, Y. Song, L. Jiang, Y. Dan, Dramatic enhancement of visible light photocatalysis due to strong interaction between $\mathrm{TiO}_{2}$ and end-group functionalized P3HT, $\begin{array}{llllll}\text { Applied } & \text { Catalysis } & \text { B: } & \text { Environmental, } & 174 & \text { (2015) }\end{array}$ https://doi.org/10.1016/j.apcatb.2015.02.034.

[25] Y. Song, F. Massuyeau, L. Jiang, Y. Dan, P. Le Rendu, T. Nguyen, Effect of graphene size on the photocatalytic activity of $\mathrm{TiO}_{2} /$ poly (3-hexylthiophene)/graphene composite films, Catalysis Today, 321 (2019) 74-80. https://doi.org/10.1016/j.cattod.2018.04.045.

[26] S. Sardar, P. Kar, H. Remita, B. Liu, P. Lemmens, S.K. Pal, S. Ghosh, Enhanced charge separation and FRET at heterojunctions between semiconductor nanoparticles and conducting polymer nanofibers for efficient solar light harvesting, Scientific Reports, 5 (2015) 17313. https://doi.org/10.1038/srep17313.

[27] N.M. Dimitrijevic, S. Tepavcevic, Y. Liu, T. Rajh, S.C. Silver, D.M. Tiede, Nanostructured $\mathrm{TiO}_{2} /$ polypyrrole for visible light photocatalysis, The Journal of Physical Chemistry C, 117 (2013) 15540-15544. https://doi.org/10.1021/jp405562b.

[28] G. Mamba, A. Mishra, Graphitic carbon nitride $\left(\mathrm{g}-\mathrm{C}_{3} \mathrm{~N}_{4}\right)$ nanocomposites: a new and exciting generation of visible light driven photocatalysts for environmental pollution remediation, Applied Catalysis B: Environmental, 198 (2016) 347-377. https://doi.org/10.1016/j.apcatb.2016.05.052. [29] S. Ghosh, H. Remita, R.N. Basu, Visible-light-induced reduction of Cr (VI) by PDPB-ZnO nanohybrids and its photo-electrochemical response, Applied Catalysis B: Environmental, 239 (2018) 
362-372. https://doi.org/10.1016/j.apcatb.2018.08.034.

[30] S. Ghosh, L. Ramos, H. Remita, Swollen hexagonal liquid crystals as smart nanoreactors: implementation in materials chemistry for energy applications, Nanoscale, 10 (2018) 5793-5819. https://doi.org/10.1039/C7NR08457A.

[31] X. Yuan, D. Floresyona, P.-H. Aubert, T.-T. Bui, S. Remita, S. Ghosh, F. Brisset, F. Goubard, H. Remita, Photocatalytic degradation of organic pollutant with polypyrrole nanostructures under UV and visible light, Applied Catalysis B: Environmental, 242 (2019) 284-292. https://doi.org/10.1016/j.apcatb.2018.10.002.

[32] D. Floresyona, F. Goubard, P.-H. Aubert, I. Lampre, J. Mathurin, A. Dazzi, S. Ghosh, P. Beaunier, F. Brisset, S. Remita, L. Ramos, R. Hynd, Highly active poly (3-hexylthiophene) nanostructures for photocatalysis under solar light, Applied Catalysis B: Environmental, 209 (2017) 23-32. https://doi.org/10.1016/j.apcatb.2017.02.069.

[33] S. Ghosh, N.A. Kouamé, L. Ramos, S. Remita, A. Dazzi, A. Deniset-Besseau, P. Beaunier, F. Goubard, P.-H. Aubert, H. Remita, Conducting polymer nanostructures for photocatalysis under visible light, Nature Materials, 14 (2015) 505-511. https://doi.org/10.1038/nmat4220.

[34] Q. Luo, X. Li, D. Wang, Y. Wang, J. An, Photocatalytic activity of polypyrrole/ $/ \mathrm{TiO}_{2}$ nanocomposites under visible and UV light, Journal of Materials Science, 46 (2011) 1646-1654. https://doi.org/10.1007/s10853-010-4981-7.

[35] S. Ghosh, N.A. Kouame, S. Remita, L. Ramos, F. Goubard, P.-H. Aubert, A. Dazzi, A. DenisetBesseau, H. Remita, Visible-light active conducting polymer nanostructures with superior photocatalytic activity, Scientific reports, 5 (2015) 1-9. https://doi.org/10.1038/srep18002.

[36] S. Ghosh, L. Ramos, S. Remita, A. Dazzi, A. Deniset-Besseau, P. Beaunier, F. Goubard, P.-H. Aubert, H. Remita, Conducting polymer nanofibers with controlled diameters synthesized in hexagonal mesophases, New Journal of Chemistry, 39 (2015) 8311-8320. https://doi.org/10.1039/C5NJ00826C.

[37] S. Ghosh, H. Remita, L. Ramos, A. Dazzi, A. Deniset-Besseau, P. Beaunier, F. Goubard, P.-H. Aubert, F. Brisset, S. Remita, PEDOT nanostructures synthesized in hexagonal mesophases, New Journal of Chemistry, 38 (2014) 1106-1115. https://doi.org/10.1039/C3NJ01349A.

[38] W. is Degussa, P25? Crystalline composition analysis, reconstruction from isolated pure particles and photocatalytic activity test, Ohtani B., Prieto-Mahaney OO, Abe R, Journal of Photochemistry and Photobiology A: Chemistry, 216 (2010) 179-182. https://doi.org/10.1016/j.jphotochem.2010.07.024. [39] N. Serpone, G. Sauve, R. Koch, H. Tahiri, P. Pichat, P. Piccinini, E. Pelizzetti, H. Hidaka, 
Standardization protocol of process efficiencies and activation parameters in heterogeneous photocatalysis: relative photonic efficiencies לr, Journal of Photochemistry and Photobiology A: Chemistry, 94 (1996) 191-203. https://doi.org/10.1016/1010-6030(95)04223-7.

[40] A. Sobczyński, Ł. Duczmal, W. Zmudziński, Phenol destruction by photocatalysis on $\mathrm{TiO}_{2}$ : an attempt to solve the reaction mechanism, Journal of Molecular Catalysis A: Chemical, 213 (2004) 225230. https://doi.org/10.1016/j.molcata.2003.12.006.

[41] U. Baig, M. Gondal, A. Ilyas, M. Sanagi, Band gap engineered polymeric-inorganic nanocomposite catalysts: Synthesis, isothermal stability, photocatalytic activity and photovoltaic performance, Journal of Materials Science \& Technology, 33 (2017) 547-557. https://doi.org/10.1016/j.jmst.2016.11.031.

[42] Y. Zhao, W. Zhu, G.Z. Chen, E.J. Cairns, Polypyrrole/TiO 2 nanotube arrays with coaxial heterogeneous structure as sulfur hosts for lithium sulfur batteries, Journal of Power Sources, 327 (2016) 447-456. https://doi.org/10.1016/j.jpowsour.2016.07.082.

[43] S. Cui, L. Yang, J. Wang, X. Wang, Fabrication of a sensitive gas sensor based on $\mathrm{PPy}_{2} \mathrm{TiO}_{2}$ nanocomposites films by layer-by-layer self-assembly and its application in food storage, Sensors and Actuators B: Chemical, 233 (2016) 337-346. https://doi.org/10.1016/j.snb.2016.04.093.

[44] S. Cao, H. Zhang, Y. Song, J. Zhang, H. Yang, L. Jiang, Y. Dan, Investigation of polypyrrole/polyvinyl alcohol-titanium dioxide composite films for photo-catalytic applications, Applied Surface Science, 342 (2015) 55-63. https://doi.org/10.1016/j.apsusc.2015.02.139.

[45] H. Remita, M.G. Méndez Medrano, C. Colbeau-Justin, Effect of Modification of $\mathrm{TiO}_{2}$ with Metal Nanoparticles on Its Photocatalytic Properties Studied by Time-Resolved Microwave Conductivity, Visible Light-Active Photocatalysis: Nanostructured Catalyst Design, Mechanisms, and Applications, (2018) 129-164.

[46] C.A. Emilio, M.I. Litter, M. Kunst, M. Bouchard, C. Colbeau-Justin, Phenol photodegradation on platinized- $\mathrm{TiO}_{2}$ photocatalysts related to charge-carrier dynamics, Langmuir, 22 (2006) 3606-3613. https://doi.org/10.1021/la051962s.

[47] F. Deng, L. Min, X. Luo, S. Wu, S. Luo, Visible-light photocatalytic degradation performances and thermal stability due to the synergetic effect of $\mathrm{TiO}_{2}$ with conductive copolymers of polyaniline and polypyrrole, Nanoscale, 5 (2013) 8703-8710. https://doi.org/10.1039/C3NR02502K.

[48] J. Li, X. Gao, X. Jiang, X.-B. Li, Z. Liu, J. Zhang, C.-H. Tung, L.-Z. Wu, Graphdiyne: A Promising Catalyst-Support To Stabilize Cobalt Nanoparticles for Oxygen Evolution, ACS Catalysis, 7 (2017) 5209-5213. https://doi.org/10.1021/acscatal.7b01781. 
[49] J. Li, X. Gao, Z. Li, J.H. Wang, L. Zhu, C. Yin, Y. Wang, X.B. Li, Z. Liu, J. Zhang, Superhydrophilic Graphdiyne Accelerates Interfacial Mass/Electron Transportation to Boost Electrocatalytic and Photoelectrocatalytic Water Oxidation Activity, Advanced Functional Materials, 29 (2019) 1808079. https://doi.org/10.1002/adfm.201808079.

[50] J. Schneider, D. Bahnemann, J. Ye, G.L. Puma, D.D. Dionysiou, Photocatalysis: fundamentals and perspectives, Royal Society of Chemistry, 2016.

[51] B. Ohtani, O.O.P. Mahaney, F. Amano, N. Murakami, R. Abe, What are titania photocatalysts? - an exploratory correlation of photocatalytic activity with structural and physical properties, Journal of Advanced Oxidation Technologies, $13 \quad$ (2010) 247-261. https://doi.org/10.1515/jaots-2010-0303.

[52] O.-O. Prieto-Mahaney, N. Murakami, R. Abe, B. Ohtani, Correlation between photocatalytic activities and structural and physical properties of titanium (IV) oxide powders, Chemistry Letters, 38 (2009) 238-239. https://doi.org/10.1246/c1.2009.238.

[53] Y. Bai, P.-Q. Wang, J.-Y. Liu, X.-J. Liu, Enhanced photocatalytic performance of direct Z-scheme $\mathrm{BiOCl}-\mathrm{g}-\mathrm{C}_{3} \mathrm{~N}_{4} \quad$ photocatalysts, RSC Advances, 4 (2014) 19456-19461. https://doi.org/10.1039/C4RA01629G.

[54] X. Li, P. Wang, B. Huang, X. Qin, X. Zhang, Q. Zhang, X. Zhu, Y. Dai, Precisely locate PdPolypyrrole on $\mathrm{TiO}_{2}$ for enhanced hydrogen production, International Journal of Hydrogen Energy, 42 (2017) 25195-25202. https://doi.org/10.1016/j.ijhydene.2017.08.153. 